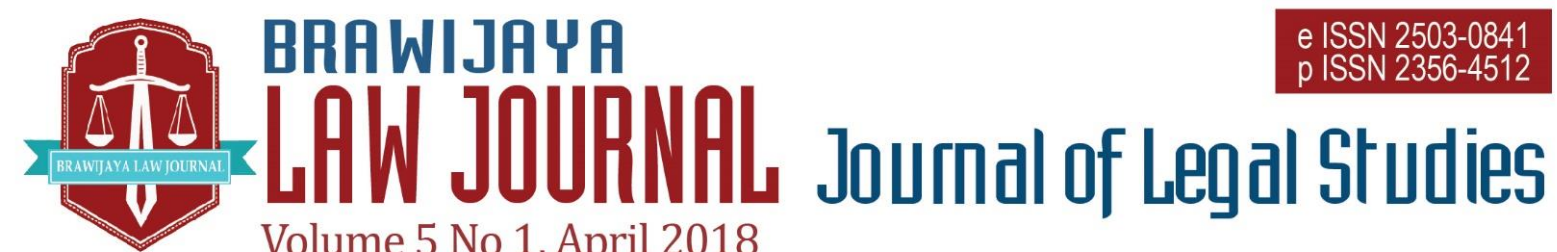

Volume 5 No 1, April 2018

Nationally Accredited No. 32a/E/KPT/2017 Dated 26th April 2017

This work is licensed under a Creative Commons Attribution-NonCommercial 4.0 International License

\title{
A Reviewof Plea Bargain Concept in the Anti- Corruption War in Nigeria
}

\author{
Akintunde Adebayo ${ }^{1}$ \\ ${ }^{1}$ Faculty of Law, Adekunle Ajasin University, Akungba-Akoko, Nigeria \\ E-mail : akintunde.adebayo@ aaua.edu.ng
}

Submitted : 2017-07-13 | Accepted : 2018-03-28

\begin{abstract}
This article aims to reviews corruption in Nigeria, the plea bargain concept, the application of plea bargain in the war against corruption in Nigeria and concludes with recommendations. Corruption in Nigeria has become endemic. There is consistent desecration of societal values with serious economic and socio-political consequences. The Nigerian government over the years has put in place several measures to combat the menace called corruption. A number of anti-corruption agencies including Economic and Financial Crimes Commission (EFCC), Independent Corrupt Practices and other Related Offences Commission (ICPC), among others have been established in order to achieve this aim. In order to address the criticism and contentions associated with the concept under the EFCC Act, the Administration of Criminal Justice Act (ACJA) was enacted in 2015. ACJA makes elaborate provision for plea bargain so as to enhance quicker dispensation of justice and help in prison decongestion.

This paper begins with brief description on anti corruption scheme established in Nigeria and endeavors to assess the strength of Nigeria's effort in plea bargain in the war against corruption, effective implementation, and compliance
\end{abstract}

Keywords: Corruption, crime, plea bargain, sentence, administration of criminal justice

\section{INTRODUCTION}

Corruption is defined as an act done with intent to give some advantages which are not consistent with the right of others or official duties. It is the wrongful use of a person's position or character to procure some benefits for himself or another, in manners contrary to the rights and duties of others. ${ }^{1}$

1 Yusuf O Ali, 'The Fight Against Corruption in Nigeria- Myth or Reality' in Yusuf O Ali (ed.),Anatomy of Corruption in Nigeria, Issues,
Black's Law Dictionary defines corruption as

1. "depravity, pervasion, or taint; an impairment of integrity, virtues, or moral principle; especially the impairment of public official's duty by bribery."

2. "The act of doing something with an intent to give some advantage inconsistent with official duty and the rights of others; a fiduciary's or official's

Challenges \& Solutions( Intec Printers Ltd 2016) 4. 
use of a station or office to procure some benefits either personally or for someone else, contrary to the rights of others."2

It has also been described by another scholar as private gain at the expense of the public. It is the misuse of public power for

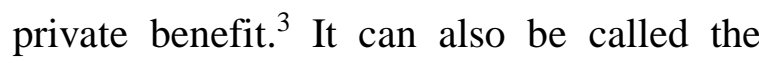
antisocial behavior of appropriating improper benefits against legal and moral norms thereby undermining, true democracy, rule of law and the efforts of authorities to improve the lot of the people. ${ }^{4}$ It is important to state that the abuse of entrusted powers for private gain negatively affects the populace who believe in and trust the integrity of such persons in positions of authority. ${ }^{5}$

Corruption pervades every sector and class of the Nigerian society, from the highest position of authority to the least position of authority there is. This ugly menace has caused the Nigerian state havoc and embarrassment ${ }^{6}$. Several trillions of Naira that would have been spent on construction of good roads, build schools, provide health quality health care, create employment for

2 B A Garner (Ed.), Black's Law Dictionary ( $7^{\text {th }}$ edn, West Group Publishing 1999) 348.

3 M McMullan, 'A Theory of Corruption' (1961) Social Review 183, 184.

4 Adebayo Adelodun, 'Moral Impropriety As a Specie of Corruption: An Expose of the Public Service in Nigeria' inYusuf O Ali (ed.), Anatomy of Corruption in Nigeria, Issues, Challenges \& Solutions(Intec Printers Ltd 2016)33.

5 Ibid, 34.

6 Obialor Collins Friday and Ozuzu Henry Ugochukwu, 'Corruption and Effective Public Service Performance in Nigeria' (2017) 5 (3) International Journal of Advanced Studies in Economics and Public Sector Management 71-72.

7 Ali (n 1) 3-4.

8 Kehinde Kolawole Eleja, 'The Bar in the Vanguard of War Against Corruption' in Yusuf O Ali (ed.), Anatomy of Corruption in Nigeria, Issues, Challenges \& Solutions (Intec Printers Ltd 2016) 176-177. the teeming youths, provide stable power supply, among others; have been diverted by some private individuals for their private use and benefits. ${ }^{7}$ One of the obvious effects is the widened the gap between the wealthy and the impoverished. It has tarnished the image of the country among the comity of nations. ${ }^{8}$

Some of the forms of corruption are:

a. Embezzlement: This involves the diversion of public funds by individuals or groups in position of authority for their private and personal use. ${ }^{9}$ Embezzlement of public funds is common. ${ }^{10}$ Bulk of these embezzled money have been deposited in foreign bank accounts thereby helping other nations where the monies are stashed to develop their economies. ${ }^{11}$ In Nigeria, the $\$ 2.1$ Billion which was earmarked for the procurement arms for the military to use to combat Boko Haram insurgency in the country was embezzled. ${ }^{12}$ The Nigerian Minister of Information and Culture, Mr. Lai Mohammed states that over $\$ 1.34$ Trillion have been stolen from the nation's treasury by 55 Nigerians between 2006

9 Press Release, 'How EFCC Recovered \$9.8 Million from Yakubu, Ex-NNPC GMD'Premium Times Newspaper (Nigeria, 10 February 2017) available online at <http://www.premiumtimesng.com/author/pressrelease $>$ accessed 10 February 2017.

10 Eze Anaba, 'Iborito Spend 4 1/2 Years in UK Prison' Vanguard Newspaper (Nigeria, 18 April 2012) available online at <http://www.vanguardngr.com/2012/04/ibori-tospend-41/2-years-in-uk-prison/> accessed 4 February 2017.

11 Yusuf Alli, 'Battle to Recover Looted Funds Shifts to Dubai'The Nation Newspaper (Nigeria, 4 February 2017) available online at $<$ http://thenationonlineng.net/battle-recoverlooted-funds-shifts-dubai/> accessed 4 February 2017.

12 Mike Uzochukwu, 'Review, Causes, Effects and Solution to Corruption in Nigeria' available online at $\quad<$ https://soapboxie.com/worldpolitics/Corruption-in-Nigeria $>$ accessed 16 January 2017. 
and $2013 .{ }^{13}$ He further states that out of the 55 persons, 15 were former governors of states in Nigeria. Mr. Mohammed alleges that the former governors have stolen $\$ 146.84$ Billion; $\$ 7$ Billion stolen by 4 former ministers; more than $\$ 14$ Billion stolen by 12 former public servants, both at federal and state levels. $\mathrm{He}$ also alleges that 8 people in the banking industry have stolen $\$ 524$ Billion and 11 businessmen linked with the theft of $\$ 653$ Billion. ${ }^{14} \mathrm{He}$ went on to state that going by the World Bank's ratio, one third of the public funds allegedly stolen by these 55 persons would have been sufficient to construct 635.18 kilometres of road; provide 36 ultra-modern hospitals (one ultra-modern hospital per state) and build 183 schools. The said amount would have been sufficient to sponsor the education of 3,974 Nigerians from primary to tertiary education level at \#25.24 Million per child and built 20,062 units of 2-bedroom apartments. ${ }^{15}$

b. Bribery: It is the offering of money, its worth, goods or services in order to gain an unfair advantage which are capable of influencing a person's decision, opinion, change the outcome of a legal or regulatory process, speed up a government grant, reduce amount of fees to be collected, among others. ${ }^{16}$

13 Sani Tukur, '55 Nigerians stole over $\$ 1.34$ Trillion in 8 years'Premium Times Newspaper(Nigeria, 18 January 2016) available online at<http://www.premiumtimesng.com/news/headli nes/196981-55-nigerians-stole-over-n1-34-

trillion-in-8-years-lai-mohammed.html> accessed 17 January 2017.

14 Ibid.

15 Ibid.

16 Ali (n 1) 5.

17 Patience A Okparavero, 'An Overview of the Various Anti-Corruption Laws in Nigeria’ (2016) 4 (1) Akungba Law Journal 59.
It is the corrupt payment, receipt or solicitation of a private favour for official action. ${ }^{17}$

A very good example of bribery is the Halliburton scam where over $\$ 180$ Million was alleged to have been given to some public officials and highly placed political office holders in Nigeria by members of staff of Halliburton Company to influence a contract for the construction of natural gas plant in the Niger Delta. ${ }^{18}$ Back in the US, in an action for bribery, Halliburton Company and its former subsidiary, Kellogg Brown \& Root pleaded guilty to the charge and consequently agreed to pay $\$ 579$ Million fine. On the other hand, in Nigeria, the top government functionaries linked to the alleged bribery of over $\$ 180$ Million bribe have not been brought to book yet. ${ }^{19}$

c. Misuse of Public Property and Funds: This involves the inappropriate use of public properties which are in custody of officials who are saddled with the responsibility of keeping such. Examples include, vehicles, landed properties, among others. ${ }^{20}$

d. Influence Peddling: It involves trading on the influence or connection with persons in high positions of authority. ${ }^{21}$

e. Favouritism and Nepotism: This is a belief that a person must always favour family,

18 Sani Tukur, 'EFCC Reopens Halliburton Bribery Case, Senior Nigerian Lawyer Quizzed, 5 others s for Probe' Premium Times Newspaper (Nigeria, 13 February 2016) available online at <http://www.premiumtimesng.com/news/headline s/198365-efcc-reopens-halliburton-bribery-casesenior-nigerian-lawyer-quizzed-5-sansprobe.html> accessed 17 January 2017.

19 Ibid.

20 Ali (n 1) 6.

21 Ibid, 7; I T Muhammad, 'Fight Against Corruption in Nigeria: Sharia Point of View' in Yusuf O Ali (ed.), Anatomy of Corruption in Nigeria, Issues, 
friends and cronies above all others in all cases, even when they ordinarily do not merit the particular thing they seek. This comes to play in employment, promotions, transfers, appointment to political offices, giving of assignments, among others. $^{22}$

f. Patronage: This involves the granting of contracts or favours to individuals by public officials or political office holders in expectation of political support and patronage. This is very common among politicians in Nigeria. ${ }^{23}$

g. Duress and Undue Influence: Cases of duress and undue influence can be found in tertiary institutions in Nigeria, lecturers using their position to take undue advantage of students. It is common to find male lecturers particularly harassing and mounting pressure on ladies in order to sleep with them in exchange for good grades. Many students who do not merit admission to tertiary institutions of learning secure admission through bribery thereby short-changing those who ordinarily would have been admitted on merit.

Other form of corruption include: Public official using private companies to get contracts or benefits from his office; ${ }^{24}$ public official transacting business during office hours; ${ }^{25}$ when a public official who has been assigned to travel by air to attend to an official engagement goes by road in order to

Challenges \& Solutions (Intec Printers Ltd 2016) 147-148.

22 Philips $\mathrm{O}$ Okolo and Akpokighe Okiemute Raymond, 'Corruption in Nigeria: The Possible Way Out' (2014) 14 (7) 35.

23 Ibid, 8.

24 Michael M Ogbeidi, Political Leadership and Corruption in Nigeria since 1960: A SocioEconomic Analysis' (2012) 1 (2) Journal of Nigerian Studies 15-16.

25 Ibid. cut cost and make some gains out of it; ${ }^{26}$ when public officials go on further studies without appropriate approval for such; ${ }^{27}$ when public officials failed to attend seminars, courses and trainings and yet claimed full financial benefits for them; ${ }^{28}$ money laundering, ${ }^{29}$ examination malpractices ${ }^{30}$, among others. This article aims to reviews corruption in Nigeria, the plea bargain concept, the application of plea bargain in the war against corruption in Nigeria.

\section{LEGAL MATERIALS AND METHODS}

This paper begins with brief description on anti corruption scheme established in Nigeria and endeavors to assess the strength of Nigeria's effort in plea bargain in the war against corruption, effective implementation, and compliance

\section{RESULTS AND DISCUSSIONS}

\section{Evolution and History of Corruption in Nigeria}

Corruption in Nigeria can be traced to the time of the country's colonialism. The British colonial government colonized Nigeria by force, undue influence and corruption. ${ }^{31}$ During colonialism, there was usurpation of powers, exploitation, injustice, inequality, domination, discrimination,

26 Rotimi Ekundayo Mathew, et.al, 'Analysis of Corruption and Economic Growth in Nigeria' (2013) 4 (4.2) Afro Asian Journal of Social Sciences 4.

27 Ibid.

28 Adelodun (n 4) 49

29 Obialor and Ozuzu (n 6) 72.

30 Omenka Iba Jacob, 'The Effect of Corruption on Development in Nigeria' (2013) 15 (6) Journal of Humanities and Social Science 40.

31 Ali (n 1) 14. 
among others. ${ }^{32}$ It therefore follows that one of the legacies Nigeria as a colony of Britain inherited after independence is corruption. ${ }^{33}$ Hence, the seed of taking undue advantages and opportunities, lack of merit, impatience sown by the colonialists have grown over the years and is thriving in the present Nigeria. ${ }^{34}$ Nigerian leaders who are following the steps of the colonialists consider the country's assets, their personal property, thus, treat as they please. ${ }^{35}$

Corruption is found in both public and private sectors. ${ }^{36}$ In the public sector, Police Officers publicly take bribes from motorists and motorcyclists, arbitrary arrest and extort money from arrested persons before they could be released on bail, among others are the norm. ${ }^{37}$ In the health sector, doctors take money from people to issue fake sick leave certificates, doctors and nurses in government owned health facilities ask for

32 Anthony A Akinola, 'Nigeria's History of Corruption' Guardian Newspaper ( Nigeria, 14 January 2015) available online at https://m.guardian.ng/opinion/columnists/akinolanigeria-s-history-of-corruption/ accessed 20 March 2018.

33 Ejovi Austine, et.al, 'Corruption in Nigeria: A Historical Perspective' (2013) 3 (16) Research on Humanities and Social Sciences 19-20.

34 Ibid.

35 Philips O Okolo and Akpokighe Okiemute Raymond (n 22) 35.

36 Shaibu Inalegwu, 'Maina, Others Defraud Police Pension Fund of $\$ 21$ Bn' Vanguard Newspaper (Nigeria, 9 March 2012) available online at<http://www.vanguardngr.com/2012/03/mainaothers-defraud-police-pension-fund-of-n21 bndcp/>accessed 17 January; Leo Sobechi, 'DiezaniAlison Madueke: Scaring the Golden Face of a Lost Era'Guardian Newspaper (Nigeria, 11 October 2015) available online at $<$ http://guardian.ng/features/policy-apolitics/diezani-alison-madueke-scaring-thegolden-face-of-a-lost-era/> accessed 12 January 2017; Bassey Udo, 'NEITI Audit Uncovers $\ 2.23$ Trillion Lost, Unremitted revenues by NNPC in 2013'Premium Times Newspaper (Nigeria, 23 May 2016) available online at <http://www.premiumtimesng.com/news/headline bribes before they carry out surgical operations or treat patients, doctors in government owned facilities divert patients to their private hospitals where they extort them, among others. ${ }^{38}$ In the judiciary, judgment now goes to the highest bidder among disputing parties. Currently, some judicial officers of superior Courts of record in the country are standing trial for various corruption related offences. ${ }^{39}$ The academia is not spared from this ugly menace as some academic staff of tertiary institutions have made passing of examinations to be dependent on purchase of 'hand-out' rather than the knowledge of the candidate on a course. Some set of students, who are considered 'special students' have the privilege of writing special examinations or getting graded specially. This of course has a price attached to it, which is either paid in cash or kind. ${ }^{40}$

s/203908-neiti-audit-uncovers-n2-23trillion-lostunremitted-revenues-by-nnpc-in-2013.html> accessed 12 January 2017.

37 Olaleye Aluko, ' 17 Policemen Arrested for Taking Bribes' Punch Newspaper (Nigeria, 2 November 2016) available online at $<$ http://punchng.com/17-policemen-arrestedtaking-bribes/> accessed 16 January 2017; Okparavero (n 16) 58-59.

38 'Medical Doctor, 3 Others Charged to Court for Corruption, Theft' available online at $<$ http://icirnigeria.org/medical-doctor-3-otherscharged-to-Court-for-corruption-theft/> accessed 17 January 2017.

39 Soni Daniel, Henry Umoru and Ikechukwu Nnochiri, 'Alleged Corruption: Justices Okoro, Ademola, Ngwuta Risk 58 years Jail' Vanguard Newspaper (Nigeria, 1 November 2016) available online at <http://www.vanguardngr.com/2016/11/allegedcorruption-justices-okoro-ademola-ngwuta-risk58-yrs-jail/> accessed 16 January 2017.

40 Femi Makinde, 'Trending: Uniosun Lecturer in Sex Scandal Video' Punch Newspaper (Nigeria, 11 August 2016) available online at $<$ http://punchng.com/uniosun-lecturer-sexscandal-video/> accessed 16 January 2017; Okparavero (n16). 
The government and her agencies are not spared from the plague of corruption. About the $15^{\text {th }}$ day of March 2014, the Federal Ministry of Interior placed a recruitment advert wherein about 676,000 applicants applied for the 4,556 positions advertised by the Nigerian Immigration Service. The applicants paid for the application forms and bought test kits. Record has it that about 18 people died nationwide following stampede at the various test venues. ${ }^{41}$ However, the then Minister of Interior, Mr. Abba Moro, two former senior officers in the Ministry and a company known as Drexel Tech Nigeria Limited were subsequently arraigned before a federal High Court, Abuja by the Economic and Financial Crimes Commission (EFCC) in February 2016. They were charged with offences of defrauding 676, 000 job applicants having paid $\mathrm{N} 1,000.00$ each for the advertised positions. $^{42}$

Surveys were conducted by Transparency International (a global civil society organization leading the fight against corruption) to determine the level of corruption among different nations between year 2000 and 2015. About 90 nations including Nigeria were reviewed. The surveys however revealed Nigeria as the most corrupt nations of all the nations

41 Leadership Editorial, 'Immigration Job Scam Forgotten?' Leadership Newspaper (Nigeria, 2 August 2014) available online at <http://leadership.ng/opinions/editorial/379760/i mmigration-job-scam-forgotten $>$ accessed 16 January 2017.

42 Ronald Mutum, 'Immigration Recruitment: EFCC Detains Abba Moro' Daily Trust Newspaper (Nigeria, 23 February 2016) available online at $<$ www.dailytrust.com/ng/news/general/immigrati on-recruitment-efcc-detains-abbamoro/134911.html> accessed 16 January 2017.

${ }^{43}$ Uzochukwu (n 11); Linus Akor, 'The Transparency International and Nigeria's Corruption Perception Index: Implications for Sustainable considered in the first year of the survey. ${ }^{43}$ The following year, Nigeria was considered the $2^{\text {nd }}$ most corrupt nation and Bangladesh being the most corrupt. ${ }^{44}$ In 2002, out of 102 nations surveyed, Nigeria still maintained $2^{\text {nd }}$ most corrupt nation in the world. ${ }^{45}$ It was the same in 2003. ${ }^{46}$ In 2004, 146 nations were examined; Bangladesh and Haiti were considered the most corrupt and $2^{\text {nd }}$ most corrupt nations respectively. Nigeria however emerged the $3^{\text {rd }}$ most corrupt nation in the world for that year. ${ }^{47} 158$ nations were appraised in 2005 and Nigeria emerged the $8^{\text {th }}$ most corrupt in the world.

In 2006, Nigeria was considered the $21^{\text {st }}$ most corrupt nation in the world for that year. ${ }^{48}$ In 2007, Nigeria out of 180 nations was regarded as the $33^{\text {rd }}$ most corrupt nation in the world. ${ }^{49}$ Nigeria took the $121^{\text {st }}$ place out of 180 nations surveyed in 2008. In 2009, Nigeria emerged $130^{\text {th }}$ out of the 180 nations surveyed. The report of the 2011 showed that Nigeria emerged $143^{\text {rd }}$ among the 183 nations covered by the survey. In the 2012 report, Nigeria ranked $135^{\text {th }}$ out of the 178 nations polled. ${ }^{50}$ In the year 2013 , Nigeria occupied the $144^{\text {th }}$ place out of 177 nations surveyed for that year. ${ }^{51}$ Nigeria took $136^{\text {th }}$ position out 174 nations appraised for the year 2014. ${ }^{52}$ Out of the 168 nations surveyed in 2015, Nigeria took $136^{\text {th }}$ place. $^{53}$

Transformations' (2014) 3 (5) Global Journal of Interdisciplinary Social Sciences 37-41.

44 'Corruption Perception Index' available online at $<$ http://www.transparency.org/research/cpi/overvi ew> accessed 17 January 2017.

45 Ibid.

${ }^{46}$ Corruption Perception Index (n 39).

${ }^{47}$ Ibid.

${ }^{48}$ Corruption Pereception Index (n 39).

49 Ibid.

${ }^{50}$ Corruption Perception Index (n 39).

51 Ibid.

${ }^{52}$ Corruption Perception Index (n 39).

53 Ibid. 


\section{Causes of Corruption in Nigeria}

Absence of National consciousness, Patriotism and Loyalty: Absence of national consciousness, patriotism and loyalty seems to be the order of the day in Nigeria. ${ }^{54}$ Tribalism and ethnicity is found in every sector. People want only people from their tribe to occupy public and political offices. Even when some of the leaders abuse their powers, reactions of Nigerians are based on sentiments depending on the tribe or ethnicity of the leader in question. That is the reason why a public official or political office holder from a particular tribe will appoint only people from his tribe, at the detriment of other Nigerians from other tribes. ${ }^{55}$

Yet another one is bad examples from leaders and mentors in the society. ${ }^{56}$ It is now common for members of the Nigerian society to condone and celebrate people who have illegitimately acquired wealth, rather than question them like it was obtainable in the olden days when morality, integrity, honesty and uprightness were greatly appreciated and valued. People publicly celebrate public officials and political office holders who are either undergoing corruption charges or have been convicted and completed terms for corruption related offences. ${ }^{57}$

Desperation for Wealth: There is now serious desperation for wealth. Our society is now such that one can only be relevant or respected when he is wealthy. This has made

54 'The Root Causes of Corruption in Nigeria' Nigerian Tribune (Nigeria, 21 July 2016) available online at <www.tribuneonlineng.com/root-causecorruption-nigeria/> accessed 20 March 2018.

55 Akor(n 38) 41.

56 Shuaib Olanrewaju Moyosore, 'Corruption in Nigeria: Causes, Effects and Probable Solutions' (2015) 1 (8) Journal of Political Science and Leadership Research 27-28.

57 O Ogundele, 'Thanksgiving Service for Ibori in Oghara'The Nation Newspaper(Nigeria, 12 February 2017) available online at so many people to resort to desperation to acquire wealth in order to be relevant and recognized in the society. This has greatly discouraged hard work, honesty and decent livelihood. ${ }^{58}$

Poor or No reward for Moral Uprightness and Integrity: Experiences have revealed that the Nigerian society and the government no longer encourage or reward moral uprightness, integrity and honesty. Persons with no integrity and moral uprightness get appointed to political offices, they get recognition in form of awards, including the national merit awards whereas those who genuinely deserve to be celebrated and given such awards are neglected and denied. This could be very discouraging for morally upright and responsible members of the society. ${ }^{59}$

Impunity: Majority of Nigerians judging from past events hold the opinion that one can get away with any corrupt act in Nigeria. ${ }^{60}$ This has spurred on and encouraged so many people to engage and continue in acts of corruption without any fears of consequences. Some individuals are as rich as the country as an entity and no one is asking them questions. This has had far reaching implications on socio-economic growth as a nation. ${ }^{61}$

Quest to survive following Systemic Failure: Many Nigerians have resorted to all sort of corrupt practices in a bid to survive the

\footnotetext{
$<$ http://thenationonlineng.net/thanksgivingservice-ibori-oghara/> accessed 13 February 2017.

59 Akor (n 43) 41-42.

60 Ibid, 44-46

61 Fola Ojo, 'Corruption: Nigeria's Giant Struggle' Punch Newspaper (Nigeria, 20 October 2017) available online $<$ https://punchng.com/corruption-nigerias-giantstruggle/> accessed 17 January 2018.
}

58 Ibid. 
hardship created by poor economic conditions, poor governance and failure of the government to provide the basic amenities of life. ${ }^{62}$ There is a high tendency for someone to compromise on integrity, honesty and morality when it comes to survival. One would rather find a way, whether legitimate or illegitimate to survive first before considering moral values. Salaries are not paid as at when due by government and even private employers, people are underpaid, there is inflation, high unemployment rate. $^{63}$ It is now called 'survival of the fittest,' as a way of justifying corrupt acts. ${ }^{64}$ It is also now very common to hear a phrase like 'all way, na way'meaning, anything is permitted, whether legitimate or illegitimate. This emphasizes desperation in the quest for survival.

\section{Consequences of Corruption}

The consequences of corruption on a country are enormous. Some of them are:

First, Desecration of Societal Values and Conscience: Corruption has succeeded in destroying our much valued moral code of conduct and conscience as a society. Gone are the days when phrases such as 'bad company corrupts good manner,' 'a good name is better than gold or silver' were guiding words in our society. Corruption has rewritten our moral codes of conduct such that conducts that are now openly endorsed and celebrated were unacceptable and abnormal some decades ago. ${ }^{65}$

\footnotetext{
62 Charles E Ekpo, et.al, 'The Irony of Nigeria's Fight against Corruption: An Appraisal of President Muhammadu Buhari's First Eight Months in Office' (2016) 4 (1) International Journal of History and Philosophical Research 63.

63 Ibid, 64

64 Akor (n 43) 43.

65 Adebayo Adenipekun, 'The Roles of Nigerian Citizens in the Fight Against Corruption' in Yusuf
}

Another pertinent consequence is its effect on the economy. They include; discouraging foreign investments, unfair distribution of wealth to the detriment and disadvantage of the masses, inflation of public spending, destabilization of national budget, hampering of economic growth, increase in public deficit, discouraging productive investment, among others. ${ }^{66}$

It can also have socio-political consequences on the society. They include; poverty, lack of guarantee for fundamental human rights, electoral malpractices, cultism, militancy, insurgency, excessive ethnic agitations, underdevelopment, insecurity, undermines democracy and rule of law, lack of good governance and public administration, among others. ${ }^{67}$

\section{Plea Bargain}

According to Langbehin, plea bargain is a non-trial mode of procedure. ${ }^{68} \mathrm{He}$ further explains that non-trial procedure undermines the constitutional provision that every citizen in all criminal charges shall be entitled to free and fair trial, within a reasonable time. When criminals were caught and charged, the government went through a trial and verdict. But in the 1800s, a trend toward plea bargaining began. It is on record that between 1880 to 1910 , almost $10 \%$ of Defendants in Alameda County, United States changed their 'not guilty' pleas to 'guilty of lesser charges' or pleaded guilty to reduced charges. ${ }^{69}$

O Ali (ed.), Anatomy of Corruption in Nigeria, Issues, Challenges \& Solutions (Intec Printers Ltd 2016) 84 .

66 Ibid, 85.

${ }^{67}$ Ibid 85-86; Mohammad (n 21) 154.

68 John H Langbehin, 'Understanding the Short History of Plea Bargaining' (1979) 13 Law and Society 261.

69 Ibid. 
A plea bargain takes place the moment a Defendant agrees to waive his or her right to a trial by pleading guilty to the offence in exchange for a reduced sentence. When this occurs, the Prosecutor will either charge the Defendant with a lesser offence, for instance, reducing a murder charge to manslaughter or uphold the current charge on the agreement to recommend a less severe sentence than the penalties recommended for such an offence. ${ }^{70}$ This is done often times in form of compromises between the parties involved, that is, the Defendant and the Prosecutor without having to go through full trial which may take several years as a result of so many factors including, unnecessary adjournments, industrial actions, among others. ${ }^{71}$ "Justice delayed they say, is justice denied."

One of the earliest cases of plea bargain was recorded in 1881. The case involved a man known as Albert McKenzie. He pleaded guilty to a charge of embezzlement in Alameda County in California. Mr. Mckenzie was at first charged with a felony for taking $\$ 52.50$ from the sewing-machine company for which he worked. However, the Prosecution and Defendant entered into a plea bargain agreement instead of going through trial. ${ }^{72}$

Again, in the popular case of Santobello v. New York, ${ }^{73}$ the legality of changing what the Defendant and Prosecutor agreed on to a more severe punishment was challenged. The Court ruled that for a plea bargain agreement to be valid, both the Prosecutor and the Defendant must consent to the terms of the agreement. In view of this

70 George Beall, 'Principles of Plea Bargaining' (1977) 9 (1) Loyola University Chicago Law Journal 175-176.

71 Ibid.

72 'Plea Bargaining Gains Favour in American Courts' available online at <http://www.history.com/this- development, the Court therefore established its approval of plea bargain by ruling that for a plea bargain agreement to be valid and binding, it must be approved by the Judge. Record has it that more than $90 \%$ of charges in the United States are resolved through plea bargain agreement. ${ }^{74}$

Plea bargain is often beneficial to both the Prosecutor and the Defendant. Still, an innocent Defendant may be persuaded to enter the agreement, giving such a Defendant the impression that going into plea bargain negotiation with the Prosecutor is the best for him or her. ${ }^{75}$ The matter of voluntariness and willingness in plea bargain agreement was raised for the first time in 1970 in the case of Brady v. United States. In that case, the Defendant, Robert Brady, attempted to change his plea after agreeing to plead guilty to the charge against him in order to get a lighter sentence. He claimed to have admitted the guilt so as to escape death penalty which is the recommended penalty for the offence upon conviction. The Supreme Court after hearing the Defendant ruled that his plea was valid because he had the option of refusing the Prosecutor's offer for a plea bargain but he did not. ${ }^{76}$

\section{Types of Plea Bargain}

a. Charge Bargain: Here the Defendant is given the option of pleading guilty to a lesser charge or to only some of the charges filed against him or her. For instance, in a situation where a Defendant is charged with murder, the prosecution may give him or her the option to plead

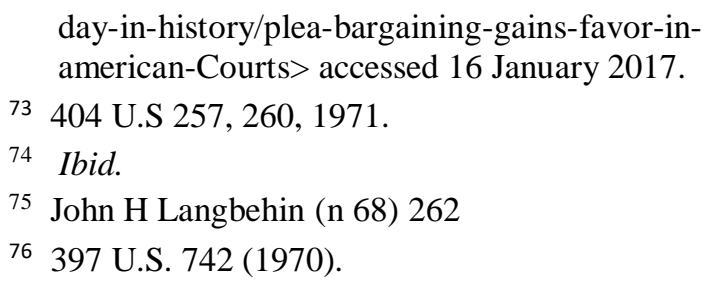


guilty to a lesser offence of attempted murder. Again, where a Defendant is charged with the offence of money laundering and embezzlement, he may plead guilty to only money laundering charge. $^{77}$

b. Sentence Bargain: Sentence can be bargained in a situation whereby a Defendant who is aware of what his sentence would be if he pleaded guilty to a particular serious offence which he is charged with may bargain with the prosecution such that he or she will plead guilty to a lesser offence with lesser punishment. For example, a Defendant who is charged with the offence of murder with the punishment being death sentence may plead guilty to attempted murder which carries life imprisonment as punishment. $^{78}$

\section{Plea Bargain in Anti-Corruption War in Nigeria}

Nigeria operates the adversarial system of criminal justice, as it is found in most common law jurisdictions and the United States. Under this system, a Defendant is presumed innocent until the contrary is proven beyond every reasonable doubt against him or her by the Prosecution. This right is guaranteed under the 1999 constitution of the Federal Republic of Nigeria. ${ }^{79}$ The prosecution in the discharge of its duty must prove its case against a Defendant beyond every reasonable doubt. ${ }^{80}$

77 Olayiwola Oluwaseyi Adebayo, 'The Concept of Plea Bargain as a Veritable Tool for Justice or Corruption'available online at <http://www.legalnaija.com/2016/09/the-conceptof-plea-bargain-as.html> accessed 27 January 2017.

78 Ibid.

791999 Constitution of the Federal Republic of Nigeria, s. 36.

${ }^{80}$ Evidence Act, s. 138 (1) and (2).
It is therefore not incumbent on a Defendant to establish his innocence; it is for the prosecution to do so. This was emphasized in the case of Ibeziako v. C.O.P. ${ }^{81}$

Where however a Defendant pleads guilty to a charge against him, he will be convicted based on the plea of guilt. This does not apply to capital offences where the punishment prescribed is death sentence. For capital offences, plea of not guilty will be recorded for a Defendant even when he or she pleads guilty. ${ }^{82}$ Also, by way of precedent, the previous decisions of a higher Court become binding on the lower ones. ${ }^{83}$

Inquisitorial system of justice on the other hand is found mostly in civil law countries. Under this system, contrary to what is obtainable under the adversarial system, it is incumbent upon the Defendant to prove his or her innocence against the complainants or persons who have accused him of the offence of which he wanted to stand trial. ${ }^{84}$ The judge here in actively involved in the investigation, preparing evidence, questioning witnesses and finding the truth cases that are brought before his Court. The Judge before the commencement of trial conducts an investigation into the alleged charge against a Defendant. Where the Judge finds clear evidence, linking the Defendant to the alleged charge, the Defendant will be presumed guilty and the Judge will proceed with the trial where the Defendant will be availed the opportunity of establishing his innocence. ${ }^{85}$ Judges in

81 (1963) 1 All NLR 61.

82 Criminal Procedure Act, s. 218 and Criminal Procedure Code, s. 187 (2).

83 'Differences between an Adversarial and an Inquisitorial Legal System' available online at $<$ http://www.ashfords.co.uk/article/differencesbetween-an-adversarial-and-an-inquisitoriallegal-system> accessed 17 January 2017.

${ }^{84}$ Ibid.

85 Ibid 
jurisdictions where inquisitorial system of justice is practised usually make decisions on a case-by-case basis. They are not bound to follow precedents. ${ }^{86}$

Having differentiated the adversarial system from the inquisitorial system of justice, it is safe to conclude that the concept of plea bargain cannot work in an inquisitorial system. It can only work in adversarial system. The reason is simple and clear, under the adversarial system, a Defendant is presumed innocent of criminal allegations against him by the prosecution have been proven beyond every reasonable doubt. It is only based on the presumption of innocence in favour of a Defendant that he can negotiate his plea with the prosecution. Under the inquisitorial system of justice, a Defendant would have been presumed guilty during pre-trial investigation and questioning by the judge therefore would have forfeited the presumption of innocence in his favour and the opportunity to negotiate his or her plea since his guilt is already presumed. ${ }^{87}$

86 Ibid.

87 'The Adversarial System vs. The Inquisitorial System' available online at <http://www.cblinternational.com/docs/csu0714/the-adversarialvs-inquisitorial-system.pdf $>$ accessed 15 January 2017.

88 ChimezieOgbonna, 'The Hue and Cry on the Application of Plea Bargain in Nigerian Criminal Justice System: Whether Necessary or Not?' available online at <http://www.narrator.ng/thehue-and-cry-on-the-application-of-plea-bargainin-nigerian-criminal-justice-system-whethernecessary-or-not/> accessed 15 January 2017; Fido, 'Obanikoro Fulfills Pact with EFCC: Returns Another $\$ 30 \mathrm{M}$, to Pay up $\mathrm{N} 417 \mathrm{M}$ ' The Herald Newspaper (Nigeria, 2 February 2017) available online at <http://www.herald.ng/obanikorofulfills-pact-with-efcc-returns-another-n30m-topay-up-n417m/> accessed 02 February 2017; George Oji and Lillian Okenwa, 'Corruption: Balogun Pleads Guilty, jailed 6 months' available online

<http://nmonlinenigeria.com/templates/?a=6126> accessed 17 January 2017; BBC News - 'Former Nigerian Bank CEO Jailed for Fraud' available online at <http://www.bbc.com/news/world-
The practice of plea bargain is a recent development in the administration of criminal justice in Nigeria. The delay in the administration of criminal justice and the need to decongest the prisons have informed the introduction of the concept. The application of the concept in the administration of criminal justice, particularly in corruption cases in Nigeria has been criticized by many Nigerians. They argue that while plea bargain may work in the advanced climes where there is integrity and people get ashamed for criminal conducts, it may not work in a society like Nigeria where the culture of impunity and lack of integrity reigns. Opponents of plea bargain also argue that it defeats the fight against corruption since it allows soft landing and less punishment for Defendants who are alleged of corruption. ${ }^{88}$

The concept of plea bargain in Nigeria was first introduced in the Economic and Financial Crimes Commission (EFCC) Act 2004. ${ }^{89}$ Sections 14-18 of the EFCC Act 2004

africa-11506421>accessed 17 January 2017; Eniola Akinkuotu, 'Plea Bargain Drama: EFCC Asks Amosu, Others to Plead Guilty, Forfeit 33 Houses' Punch Newspaper (Nigeria, 10 July 2016) available online at <http://punchng.com/pleabargain-drama-efcc-asks-amosu-others-pleadguilty-forfeit-33-houses/> accessed 17 January 2017; Clement A Oloyede, 'Anti-Graft War and Plea bargain Mechanism: What Should be Done' Daily Trust Newspaper (Nigeria, 23 July 2016) available online at <http://www.dailytrust.com.ng/news/law/antigraft-war-and-plea-bargain-mechanism-whatshould-be-done/159869.html> accessed 17 January 2017; Clement A Oloyede, 'Anti-Graft War and Plea bargain Mechanism: What Should be Done' Daily Trust Newspaper (Nigeria, 23 July 2016) available online at <http://www.dailytrust.com.ng/news/law/antigraft-war-and-plea-bargain-mechanism-whatshould-be-done/159869.html> accessed 17 January

89 'Subject to the provisions of section 174 of the Constitution of the Federal Republic of Nigeria 1999, the Commission may compound any offence punishable under this Act by accepting such sums 
provides for offences which the Commission can exercise jurisdiction. They include: financial malpractices, terrorism related offences, Retention of proceeds of criminal conduct by public officers and economic as well as financial crimes. The Act also enables the Commission to enter plea bargain agreement with anyone who has been alleged of a financial crime such that the Commission and the Defendant will negotiate and consequently reduce the charges or sentences against him or her provided the suspect is ready to forfeit and return the loot and proceeds of financial crime. ${ }^{90}$ The Administration of Criminal Justice Laws of Lagos State 2007 also provided for the concept in Lagos State. ${ }^{91}$

After much criticism about the legality of the concept in the administration of criminal justice in Nigeria, the National Assembly of the Federal Republic of Nigeria in 2015 promulgated the Administration of Criminal Justice Act (ACJA). ${ }^{92}$ The Act made elaborate provision for the concept and also introduced some stringent measures to ensure efficient and effective application of the concept. Unlike the ACJL of Lagos State which limits the power to accept plea bargain to only the Attorney-General and Commissioner of Justice of the state, the ACJA provides that any Prosecutor may receive plea bargain offer from the Defendant or offer same to a Defendant. ${ }^{93}$ The Prosecution is enjoined to accept or give the offer of plea bargain where it considers that

of money as it thinks fit, exceeding the maximum amount to which that person would have been liable if he had been convicted of that offence.'

90 EFCC Act 2004, s. 13 and 14.

91 Administration of Criminal Justice Laws (ACJL) of Lagos State 2007, s. 76 (1) - (10).

92 Administration of Criminal Justice Act (ACJA) 2015, s. 270 (1) - (18).

$93 \operatorname{ACJA}($ n 82) s. 270 (1); ACJL Lagos State (n 81) s. 75. it is in the best interest of justice, general public and prevention of abuse of legal process. ${ }^{94}$ Also, the ACJL of Lagos State provides that plea bargain agreement can only be entered into before the plea of the Defendant is taken while the ACJA provides that plea bargain agreement could be entered into at any time prior to the Defendant entering his defence. However, certain conditions must be satisfied. ${ }^{95}$ They are: ${ }^{96}$

a. If the Prosecution after examining the available evidence is of the opinion that it may not be sufficient to establish the case beyond reasonable doubt, in a bid to save time, efforts and resources may consider plea bargain;

b. If the Defendant has agreed to return all the loot and proceeds of crime;

c. If the Defendant in a case of conspiracy has agreed to work with the Prosecution to investigate and prosecute co-offenders.

The Prosecutor and Defendant or his representative may agree in writing with respect to the sentence to be imposed on the Defendant and other relevant things before plea bargain agreement. ${ }^{97}$ The said agreement shall be transmitted to the Attorney-General of the Federation and the presiding Judge of the Court where the case is pending shall not involved in the negotiation leading to the agreement but the Court shall be duly informed about such an agreement. ${ }^{98}$ Upon information of the plea

94 ACJA (n 82) s. 270 (3).

95 ACJA(n 82) s. 270 (2); F E Ojeih and D O Okanyi, 'The Administration of Criminal Justice Act, 2015: An Appraisal' (2016) 7 Ekiti State University, Ado-Ekiti Law Journal519-522.

96 ACJA (n 82) s. 270 (2).

97 ACJA (n 82)s. 270 (4), (5), (6) and (7).

98 ACJA (n 82)s. 270 (8), (9), (10). 
bargain agreement, the Court shall ascertain the admittance of the Defendant to the allegations against him and the voluntariness of the plea bargain agreement.

In appropriate cases, the Court will direct that the loot (money, assets) which parties have agreed to be forfeited under the plea bargain agreement be transmitted to the appropriate victims or persons. ${ }^{99}$ Anyone who willfully or without just cause obstructs the successful transfer of such loots to the appropriate persons or bodies entitled to them will be guilty of an offence and liable upon conviction to 7 years jail term. ${ }^{100}$ The pronouncement of the Court following a plea bargain agreement which has been ascertained to be voluntary and free from duress shall be final and not appealable except where fraud is alleged. ${ }^{101}$

From the foregoing, it can be said that the concept of plea bargain in Nigeria is laudable as it is designed to enhance speedier dispensation of justice and to curb the ever rising awaiting trial prison population. The concept under the ACJA does not absolve a Defendant of allegations against him as he is still considered a convict whose name must be entered in the central criminal records registry within 30 days from the date the judgment was entered. ${ }^{102}$

\section{CONCLUSIONS AND SUGGESTIONS}

This research discovered that while the concept of plea bargain is laudable and primarily meant to arrest the lingering challenges of delay in the dispensation of justice and prison congestion in the administration of criminal justice in Nigeria, caution must be employed in the use of the concept when it comes to corruption related cases. The concept however has been criticized by members of the society that it enables the rich to easily escape sanctions. This conclusion must have been reached considering the number of cases involving prominent politicians, top government officials, former bank chiefs, among others who have gotten soft landing through plea bargain agreement. This has been considered an affront to justice and inimical to the fight against corruption which has remained a major clog in the wheels of development in Nigeria.

The anti-corruption agencies must therefore be careful in the application of the concept to corruption cases they are handling in order to ensure that it is not abused so as not to make it an escape route for persons who have embezzled public funds or who are guilty of other financial crimes. Where the concept of plea bargain is misapplied or abused in corruption related cases, it will defeat the essence of punishment which is to serves as deterrence to others with similar intention. A situation where officials of Nigerian anti-corruption bodies and financial crime offenders are cronies who are readily available to initiate plea bargain will frustrate the anti-corruption initiative and efforts in Nigeria. It will create a situation whereby offenders get away easily with corruption charges against them and consequently encourage corruption in the society.

\footnotetext{
99 ACJA (n 82) s. 270 (12), (13).

100 ACJA (n 82) s. 270 (14).
} 


\section{REFERENCES}

\section{Chapters in a Book}

Adelodun, Adebayo, 'Moral Impropriety As a Specie of Corruption: An Expose of the Public Service in Nigeria' inYusuf O Ali (ed.), Anatomy of Corruption in Nigeria, Issues, Challenges \& Solutions(Intec Printers Ltd 2016) 33. Adenipekun, Adebayo, 'The Roles of Nigerian Citizens in the Fight Against Corruption' in Yusuf O Ali (ed.), Anatomy of Corruption in Nigeria, Issues, Challenges \& Solutions (Intec Printers Ltd 2016) 84.

Muhammad, I T, 'Fight Against Corruption in Nigeria: Sharia Point of View' in Yusuf O Ali (ed.), Anatomy of Corruption in Nigeria, Issues, Challenges \& Solutions (Intec Printers Ltd 2016) 147-148.

Eleja, Kehinde Kolawole, 'The Bar in the Vanguard of War Against Corruption' in Yusuf O Ali (ed.), Anatomy of Corruption in Nigeria, Issues, Challenges \& Solutions (Intec Printers Ltd 2016) 176-177.

Ali, Yusuf O, 'The Fight Against Corruption in Nigeria- Myth or Reality' in Yusuf O Ali (ed.),Anatomy of Corruption in Nigeria, Issues, Challenges \& Solutions( Intec Printers Ltd 2016) 4.

\section{Journal Articles}

Ekpo, Charles E, J Chime and F Enor, 'The Irony of Nigeria's Fight against Corruption: An Appraisal of President Muhammadu Buhari's First Eight Months in Office' (2016) 4 (1) International Journal of History and Philosophical Research 63

Austine, Ejovi, Mgbonyebi Voke Charles and Akpokighe Okiemute Raymond,
'Corruption in Nigeria: A Historical Perspective' (2013) 3 (16) Research on Humanities and Social Sciences 1920

Ojeih, F E and D O Okanyi, 'The Administration of Criminal Justice Act, 2015: An Appraisal' (2016) 7 Ekiti State University, Ado-Ekiti Law Journal519-522

Beall, George, 'Principles of Plea Bargaining' (1977) 9 (1) Loyola University Chicago Law Journal 175176

Langbehin, John H, 'Understanding the Short History of Plea Bargaining' (1979) 13Law and Society 261.

Akor, Linus, 'The Transparency International and Nigeria's Corruption Perception Index: Implications for Sustainable Transformations' (2014) 3 (5) Global Journal of Interdisciplinary Social Sciences 37-41.

McMullan, M, 'A Theory of Corruption' (1961) Social Review 183, 184.

Ogbeidi, Michael M, Political Leadership and Corruption in Nigeria since 1960: A Socio-Economic Analysis' (2012) 1 (2) Journal of Nigerian Studies 15-16.

Friday, Obialor Collins and Ozuzu Henry Ugochukwu, 'Corruption and Effective Public Service Performance in Nigeria' (2017) 5 (3) International Journal of Advanced Studies in Economics and Public Sector Management 71-72.

Jacob, Omenka Iba, 'The Effect of Corruption on Development in Nigeria' (2013) 15 (6) Journal of Humanities and Social Science 40.

Okparavero, Patience A, 'An Overview of the Various Anti-Corruption Laws in 
Nigeria' (2016) 4 (1) Akungba Law Journal 59.

Okolo, Philips O and Akpokighe Okiemute Raymond, 'Corruption in Nigeria: The Possible Way Out' (2014) 14 (7) 35.

Mathew, Rotimi Ekundayo, Obasaju Barnabas, Lawal, AdedoyinIsola and Iseolorunkanmi Joseph, 'Analysis of Corruption and Economic Growth in Nigeria' (2013) 4 (4.2) Afro Asian Journal of Social Sciences 4.

Moyosore, Shuaib Olanrewaju, 'Corruption in Nigeria: Causes, Effects and Probable Solutions' (2015) 1 (8) Journal of Political Science and Leadership Research 27-28.

\section{Constitution}

1999 Constitution of the Federal Republic of Nigeria

\section{Statutes}

Administration of Criminal Justice Act 2015 Administration of Criminal Justice Laws of Lagos State 2007

Criminal Procedure Act, Laws of the Federation of Nigeria 2004

Criminal Procedure Code, Laws of the Federation of Nigeria 2004

Economic and Financial Crimes Commission (EFCC) Act

Evidence Act 2011

\section{Case Laws}

Brady v. United States, 397 U.S. 742 (1970). Ibeziako v. C.O.P, (1963) 1 All NLR 61. Santobello v. New York, 404 U.S 257, 260 (1971).

\section{Dictionary}

B A Garner (Ed.), Black's Law Dictionary $\left(7^{\text {th }}\right.$ edn, West Group Publishing 1999) 348.

\section{Newspaper (online)}

Bassey Udo, 'NEITI Audit Uncovers \$2.23 Trillion Lost, Unremitted revenues by NNPC in 2013'Premium Times Newspaper (Nigeria, 23 May 2016) available online at <http://www.premiumtimesng.com/ne ws/headlines/203908-neiti-audituncovers-n2-23trillion-lostunremitted-revenues-by-nnpc-in2013.html>

Clement A Oloyede, 'Anti-Graft War and Plea bargain Mechanism: What Should be Done' Daily Trust Newspaper (Nigeria, 23 July 2016) available online at <http://www.dailytrust.com.ng/news/l aw/anti-graft-war-and-plea-bargainmechanism-what-should-bedone/159869.html>

Clement A Oloyede, 'Anti-Graft War and Plea bargain Mechanism: What Should be Done' Daily Trust Newspaper (Nigeria, 23 July 2016) available online at <http://www.dailytrust.com.ng/news/l aw/anti-graft-war-and-plea-bargainmechanism-what-should-bedone/159869.html>

Eniola Akinkuotu, 'Plea Bargain Drama: EFCC Asks Amosu, Others to Plead Guilty, Forfeit 33 Houses' Punch Newspaper (Nigeria, 10 July 2016) available online at <http://punchng.com/plea-bargaindrama-efcc-asks-amosu-others-pleadguilty-forfeit-33-houses/>

EzeAnaba, 'Iborito Spend 4 1/2 Years in UK Prison' Vanguard Newspaper (Nigeria, 18 April 2012) available online at <http://www.vanguardngr.com/2012/0 4/ibori-to-spend-41/2-years-in-ukprison/> 
Femi Makinde, 'Trending: Uniosun Lecturer in Sex Scandal Video' Punch Newspaper (Nigeria, 11 August 2016) available online at $<$ http://punchng.com/uniosunlecturer-sex-scandal-video/>

Fido, 'Obanikoro Fulfills Pact with EFCC: Returns Another $\$ 30 \mathrm{M}$, to Pay up N417M' The Herald Newspaper (Nigeria, 2 February 2017) available online at

<http://www.herald.ng/obanikoro-

fulfills-pact-with-efcc-returns-anothern30m-to-pay-up-n417m/>

George Oji and Lillian Okenwa, 'Corruption:

Balogun Pleads Guilty, jailed 6 months' available online at $<$ http://nmonlinenigeria.com/templates /?a=6126>

Leadership Editorial, 'Immigration Job Scam Forgotten?' Leadership Newspaper (Nigeria, 2 August 2014) available online at

<http://leadership.ng/opinions/editoria 1/379760/immigration-job-scamforgotten>

O Ogundele, 'Thanksgiving Service for Ibori in Oghara' The Nation Newspaper (Nigeria, 12 February 2017) available online at $<$ http://thenationonlineng.net/thanksgi ving-service-ibori-oghara/>

Olaleye Aluko, '17 Policemen Arrested for Taking Bribes'Punch Newspaper (Nigeria, 2 November 2016) available online at $<$ http://punchng.com/17policemen-arrested-taking-bribes/>

Press Release, 'How EFCC Recovered \$9.8 Million from Yakubu, Ex-NNPC GMD'Premium Times Newspaper (Nigeria, 10 February 2017) available online at $<$ http://www.premiumtimesng.com/au thor/press-release> accessed 10 February 2017.

Ronald Mutum, 'Immigration Recruitment: EFCC Detains Abba Moro' Daily Trust Newspaper (Nigeria, 23 February 2016) available online at <www.dailytrust.com/ng/news/general /immigration-recruitment-efccdetains-abba-moro/134911.html>

Sani Tukur, '55 Nigerians stole over $\$ 1.34$ Trillion in 8 years'Premium Times Newspaper(Nigeria, 18 January 2016) available online at $<$ http://www.premiumtimesng.com/ news/headlines/196981-55-nigeriansstole-over-n1-34-trillion-in-8-yearslai-mohammed.html>

Sani Tukur, 'EFCC Reopens Halliburton Bribery Case, Senior Nigerian Lawyer Quizzed, 5 others s for Probe' Premium Times Newspaper (Nigeria, 13 February 2016) available online at <http://www.premiumtimesng.com/ne ws/headlines/198365-efcc-reopenshalliburton-bribery-case-seniornigerian-lawyer-quizzed-5-sansprobe.html>

Shaibu Inalegwu, 'Maina, Others Defraud Police Pension Fund of $¥ 21$ Bn’ Vanguard Newspaper (Nigeria, 9 March 2012) available online at $<$ http://www.vanguardngr.com/2012 /03/maina-others-defraud-policepension-fund-of-n21bn-dcp/>accessed 17 January; Leo Sobechi, 'DiezaniAlison Madueke: Scaring the Golden Face of a Lost Era'Guardian Newspaper (Nigeria, 11 October 2015) available online at <http://guardian.ng/features/policy-apolitics/diezani-alison-maduekescaring-the-golden-face-of-a-lost$\underline{\mathrm{era} />}$ 
Soni Daniel, Henry Umoru and Ikechukwu Nnochiri, 'Alleged Corruption: Justices Okoro, Ademola, Ngwuta Risk 58 years Jail' Vanguard Newspaper (Nigeria, 1 November 2016) available online

at <http://www.vanguardngr.com/2016/1 1/alleged-corruption-justices-okoroademola-ngwuta-risk-58-yrs-jail/>

Yusuf Alli, 'Battle to Recover Looted Funds Shifts to Dubai'The Nation Newspaper (Nigeria, 4 February 2017) available online at http://thenationonlineng.net/battlerecover-looted-funds-shifts-dubai/

\section{Web Sources}

'Differences between an Adversarial and an Inquisitorial Legal System' available online at <http://www.ashfords.co.uk/article/dif ferences-between-an-adversarial-andan-inquisitorial-legal-system>

'The Adversarial System vs. The Inquisitorial System' available online at <http://www.cblinternational.com/docs/csu0714/theadversarial-vs-inquisitorialsystem.pdf>

BBC News - 'Former Nigerian Bank CEO Jailed for Fraud' available online at <http://www.bbc.com/news/worldafrica-11506421>

Chimezie Ogbonna, 'The Hue and Cry on the Application of Plea Bargain in Nigerian Criminal Justice System: Whether Necessary or Not?' available online at <http://www.narrator.ng/thehue-and-cry-on-the-application-ofplea-bargain-in-nigerian-criminaljustice-system-whether-necessary-or$\underline{\text { not/> }}$
Corruption Perception Index' available online at $<$ http://www.transparency.org/researc h/cpi/overview>

Medical Doctor, 3 Others Charged to Court for Corruption, Theft' available online at <http://icirnigeria.org/medicaldoctor-3-others-charged-to-Court-forcorruption-theft/>

Mike Uzochukwu, 'Review, Causes, Effects and Solution to Corruption in Nigeria' available online at <https://soapboxie.com/worldpolitics/Corruption-in-Nigeria>

Olayiwola Oluwaseyi Adebayo, 'The Concept of Plea Bargain as a Veritable Tool for Justice or Corruption'available online at <http://www.legalnaija.com/2016/09/t he-concept-of-plea-bargain-as.html $>$

Plea Bargaining Gains Favour in American Courts' available online at <http://www.history.com/this-day-inhistory/plea-bargaining-gains-favorin-american-Courts> 